\title{
TINJAUAN ETIKA TERHADAP PENGGUNAAN FREON UNTUK MESIN PENDINGIN DALAM FILSAFAT ILMU
}

\author{
Yulianti Yusal* \\ Sekolah Pascasarjana Universitas Pendidikan Indonesia \\ *E-mail: ulhyje@gmail.com
}

\begin{abstract}
Abstrak
Etika adalah salah satu cabang filsafat perwujudan dan pengejawantahan secara kritis dan rasional ajaran moral yang siap pakai sedangkan moral adalah petunjuk konkret yang siap pakai tentang bagaimana kita harus hidup. Disiplin etika lebih bersifat normatif dan perspektif. Kaidah-kaidah etika perlu dipergunakan dalam menentukan objek penelitian dan aplikasi pengetahuan agar terhindar dari kemunculan dampak negatif dari riset sains dan penerapan pengetahuan sains di masyarakat, seperti kerusakan lingkungan dan dehuminasi. Ilmu pengetahuan dan teknologi seharusnya secara etis dimanfaatkan demi kelestarian alam sebagai prasyarat kelangsungan eksistensi manusia. Seperti pada penggunaan freon untuk mesin pendingin yang berkontribusi pada kenyamanan dan pelestarian bahan makanan melalui pendinginan atau pembekuan tapi bisa mengancam lingkungan melalui penipisan ozon dan pemanasan global. Oleh karena itu, penggunaan freon untuk mesin pendingin sebaiknya dihentikan dan menggantinya sebagai bentuk tanggung jawab untuk mewujudkan perubahan yang terbaik dalam teknologi mesin pendingin untuk pembangunan.
\end{abstract}

Kata kunci: Etika, Freon, Mesin Pendingin

\section{PENDAHULUAN}

Teknologi adalah aplikasi pengetahuan sains terapan dalam skala industri untuk menghasilkan produk-produk komersial (Firman, 2017). Mengingat, pertumbuhan penduduk yang meningkat diiringi oleh meningkatnya kebutuhan manusia. Oleh karena itu, hasil teknologi dari aplikasi pengetahuan sains tentunya sangat dibutuhkan oleh manusia untuk mengatasi berbagai masalah seperti kebutuhan sandang, kebutuhan pangan, kebutuhan energi, dan kebutuhan kesehatan (Latif, 2014).

Salah satu produk dari hasil teknologi yang sangat dibutuhkan manusia dalam kehidupannya adalah mesin pendingin dengan freon. Mesin pendingin dengan freon dapat digunakan untuk melestarikan bahan makanan melalui pendinginan atau pembekuan sehingga mengurangi kerugian selama pemrosesan, penyimpanan, transportasi, dan penjualan bahan makanan tersebut. Sistem AC yang dapat membantu meningkatkan kenyamanan manusia untuk keperluan pribadi maupun komersil dan untuk menjaga kesehatan. Meskipun kemajuan teknologi ini mungkin berkontribusi pada kenyamanan manusia akan tetapi bisa mengancam lingkungan melalui penipisan ozon dan pemanasan global (UNEP, 2003). Oleh karena itu, ilmuan, pemerintah maupun masyarakan mengalami dilema karena disatu sisi sangat membantu dalam kehidupan manusia tapi disisi lain mengakibatkan masalah lingkungan.

Dilema-dilema etis yang berhubungan dengan penelitian dan aplikasi pengetahuan sains dalam memberikan pertimbangan rasional merupakan tugas etika sains. Etika sains merupakan salah satu bidang etika yang berbicara tentang masalah-masalah etis dalam penelitian dan aplikasi pengetahuan sains. Etika adalah cabang filsafat yang mengkaji prinsip-prinsip moral yang mengatur perilaku seseorang, disebut juga filsafat moral. Disiplin etika lebih bersifat normatif dan perskriptif daripada deskriptif atau eksplanatori. Oleh karena itu, kaidah-kaidah etika perlu dipergunakan dalam menentukan objek penelitian dan aplikasi pengetahuan sains agar 
terhindar dari kemunculan dampak negatif dari riset sains dan aplikasi pengetahuan sains di masyarakat (Firman, 2017).

Menurut Firman (2017), untuk mewujudkan etika sains dalam aktivitas sains, dirumuskan sejumlah prinsip etika sains yaitu: (1) universal: sains bebas dari ras, warna kulit, kewarganegaraan, dan agama; (2) komunal: pengetahuan ilmiah harus menjadi pengetahuan publik, hasil riset harus dipublikasikan, harus ada kebebasan untuk bertukar informasi ilmiah antar ilmuan dimanapun, ilmuan harus bertanggung jawab kepada masyarakat ilmuan akan kredibilitas karya yang dipublikasikannya; (3) tanpa kepentingan hasil riset ilmiah harus tidak dimanipulasi untuk kepentingan profit, ideologi, dan politik (ilmuan harus jujur dan objektif); (4) skeptis: pernyataan -pernyataan harus tidak diterima nerdasarkan otoritas, tetapi ilmuan harus bebas mempertanyakan pernyataanpernyataan tersebut, serta kebenaran pernyataan harus didukung oleh fakta observasi.

Berdasarkan penjelasan diatas dapat disimpulkan bahwa etika sains dapat digunakan untuk meninjau penggunaan feron untuk mesin pendingin, maka tulisan ini disajikan untuk menganalisis tinjauan etika terhadap penggunaan feron untuk mesin pendingin. Adapun rumusan masalahnya:

1. Bagaimana etika dalam filsafat ilmu?

2. Bagaimana penggunaan feron untuk mesin pendingin?

3. Bagaimanakah tinjauan etika terhadap penggunaan feron untuk mesin pendingin?

\section{PEMBAHASAN}

\section{Etika dalam Filsafat IImu}

Aksiologi adalah salah satu cabang filsafat yang diartikan sebagai teori nilai yang berkaitan dengan kegunaan pengetahuan yang diperoleh. Aksiologi berhubungan dengan penggunaan ilmu pengetahuan. Etika adalah salah satu bagian dari cabang filsafat Aksiologi (Latif, 2014). Etika berakar dari bahasa Yunani 'ethikos', atau 'ethos' yang berarti adat atau kebiasaan. Selanjutnya ethikos berkembang menjadi ekuivalen dengan moralitas. Dari kedua istilah tersebut, tersirat hubungan dengan kegiatan praktis yaitu perilaku. Perilaku etis bersangkutan dengan perbuatan yang bernilai baik dan benar. Etika sering diartikan sebagai filsafat moral atau 'filsafat tingkah laku' (Suhartono, 2008).

Sebagai cabang filsafat, etika adalah refleksi kritis dan rasional mengenai nilai dan moral yang menentukan dan terwujud dalam sikap dan pola perilaku kehidupan manusia, baik secara pribadi maupun sebagai kelompok. Etika adalah perwujudan dan pengejawantahan secara kritis dan rasional ajaran moral yang siap pakai, sedangkan moral adalah petunjuk konkret yang siap pakai tentang bagaimana kita harus hidup. Bedanya bahwa moral/moralitas langsung mengatakan "Inilah caranya Anda harus melangkah". Sedangkan etika justru mempersilahkan; "Apa saya harus melangkah dengan cara itu?", dan "Mengapa harus dengan cara itu?"(Suseno \& Salam dalam Ihsan, 2010).

Makna etika dipakai dalam dua bentuk arti: pertama, etika merupakan suatu kumpulan pengetahuan mengenai penilaian terhadap perbuatan manusia. Kedua, merupakan suatu predikat yang dipakai untuk membedakan halhal, perbuatan, atau manusia lain. Objek formal etika meliputi norma kesusilaan manusia dan mempelajari baik buruknya tingkah laku manusia. Adapun estetika berkaitan dengan nilai tentang pengalaman keindahan yang dimiliki oleh manusia terhadap lingkungan dan fenomena disekelilingnya. Nilai itu objektif atau subjektif sangat bergantung dari hasil pandangan yang muncul dari filsafat. Nilai akan menjadi subjektif apabila subjek sangat berperan dalam segala hal, kesadaran manusia menjadi tolok ukur segalanya, atau eksistensinya, maknanya dan validitasnya tergantung pada reaksi subjek yang melakukan penilaian tanpa mempertimbangkan apakah ini bersifat fisik atau psikis. Dengan demikian, nilai subjektif akan selalu memperhatikan berbagai pandangan yang dimiliki akal budi manusia, seperti mengarah kepada suka atau tidak suka, senang atau tidak senang. Nilai itu ojektif jika ia tidak bergantung pada subjek atau keadaan yang menilai. Nilai objektif muncul karena adanya pandangan dalam filsafat tentang 
objectivisme. Objectivisme ini beranggapan pada tolok ukur suatu gagasan berada pada objeknya, sesuatu yang memiliki kadar secara realitas benar-benar ada sesuai dengan objek sesungguhnya (Latif, 2014).

Prinsip etik atau moral ada yang besifat objektivistik-universal dan ada pula prinsip etik atau moral yang bersifat relativistik-kontekstual. Prinsip etik atau moral ada yang besifat objektivistik-universal yang dimaksudkan yaitu prinsip moral secara objektif dapat diterima oleh siapapun, dimanapun, dan kapanpun juga. Sebagai contoh, sifat atau sikap kejujuran, kemanusiaan, kemerdekaan, tanggung jawab, keikhlasan, ketulusan, persaudaraan, dan keadilan. Adapun prinsip moral yang bersifat relativistik kontekstual sifatnya "tergantung atau sesuai dengan konteks", misalnya tergantung pada konteks kebudayaan atau kultur, sehingga bersifat kultural. Demikian seterusnya, sifat relativistik kontekstual itu pengertiannya bisa berarti nasional, komunal, tradisional, situasional, kondisional, multikultural, atau bahkan individual (Latif, 2014).

Etika sebagai ilmu biasa dibedakan menjadi tiga macam, yaitu etika deskriptif, etika normatif, dan meta-etika. Etika deskriptif mempelajari tingkah laku moral dalam arti luas, seperti adat kebiasaan, pandangan tentang adat baik dan buruk, perbuatan yang diwajibkan, dibolehkan, atau dilarang dalam suatu masyarakat, lingkungan budaya atau periode sejarah. Etika desriptif tugasnya sebatas menggambarkan atau memperkenalkan dan sama sekali tidak memberikan penilaian moral. Etika normatif bertujuan merumuskan prinsip etis yang dapat dipertanggungjawabkan secara rasional dan dapat diterapkan dalam perbuatan nyata. Berbeda dengan etika deskriptif, etika normatif tidak bersifat netral tetapi memberikan penilaian terhadap tingkah laku moral berdasar norma-norma tertentu. Etika normatif tidak sekedar mendeskripsikan atau menggambarkan, melainkan bersifat perspektif atau memberikan petunjuk mengenai baik atau tidak baik, boleh atau tidak bolehnya suatu perbuatan. Untuk itu, didalamnya dikemukakan argumen atau diskusi yang mendalam, dan etika normatif merupakan bagian penting dari etika. Ada juga meta-etika yang dikenal secara popular, dia tidak membahas persoalan moral dalam arti baik atau buruknya suatu tingkah laku, tetapi membahas bahasa moral. Metaetika seolah-olah bergerak pada taraf yang lebih tinggi daripada perilaku etis, dengan bergerak pada taraf bahasa etis (Latif, 2014).

Persoalan pokok etika dapat dirumuskan 'bagaimana seharusnya manusia bertingkah laku, apa yang menjadi dasar dan tujuan perilaku, dan tanggung jawab apa yang dapat diberikan sehingga perilaku bernilai guna bagi kehidupan. Dalam hubungannya dengan ilmu pengetahuan, kebenaran ilmiah dengan nilai kemanfaatannya harus menjadi tolok ukur perilaku. Suatu perilaku mengandung nilai baik apabila mengandung nilai kebenaran ilmiah dan bermanfaat bagi pencapaian tujuan kehidupan manusia dan masyarakatnya (Suhartono, 2008). Tujuan etika dalam ilmu pengetahuan yaitu agar seorang ilmuan dapat menerapkan prinsip-prinsip moral yaitu yang baik dan yang menghindarkan dari yang buruk kedalam perilaku keilmuannya. Pada masa awal perkembangan, ilmu sering kali berbenturan dengan nilai moral yang diyakini oleh masyarakat (Latif, 2014).

Aspek etika ilmu pengetahuan adalah tentang konkret individual ilmu pengetahuan seperti halnya manusia, ia barulah berfungsi ketika menjadi konkret individual. Begitu juga halnya ilmu pengetahuan baru dapat difungsikan ketika teori-teori ilmiah dibangun menjadi sebuah 'sistem teknologi'. IImu pengetahuan dan teknologi seharusnya secara etis dimanfaatkan demi kelestarian alam sebagai prasyarat kelangsungan eksistensi manusia. Dengan ilmu pengetahuan dan teknologi serta perindustrian, manusia harus tetap dalam kesadarannya bahwa tugas dan kewajiban pertama dan utamanya adalah menjaga kelangsungan alam. Jadi, rancang bangun teknologi dibuat berdasar pada teoriteori kebenaran ilmiah, semata-mata untuk tujuan pemberdayaan nilai-nilai kebenaran ilmiah yaitu kemanfaatan bagi kelangsungan kehidupan dan bagi tercapainya tujuan kehidupan secara cepat dan mudah (Suhartono, 2008). 


\section{Freon Untuk Mesin Pendingin}

Mesin pendingin merupakan mesin yang bertujuan untuk mengambil sebanyak mungkin kalor dari tendon dingin dengan melakukan kerja sekecil mungkin dapat dikatakan 'keluarannya' adalah kalor yang diambil dari tendon dingin dan 'masukannya' adalah kerja seperti pada Gambar 1. Jadi, ukura kinerja pesawat pendingin, yang mudah bagi kita, dinyatakan oleh koefisien kinerja (yang disebut juga nisbah energi pendingin) (Zemasky \& Ditman, 1986).

$$
\omega=\frac{\text { kalor yang diambil dari tandon dingin }}{\text { kerja yang dilakukan pada zat pendingin }}
$$

Jika dalam satu daur, kalor $Q_{c}$ diserap oleh zat pendingin dari tendon dingin dan kerja $|W|$ dilakukan oleh motor listrik yang menjalankan pesawat pendingin maka:

$$
\omega=\left|\frac{Q_{c}}{W}\right|=\frac{\left|Q_{c}\right|}{\left|Q_{H}\right|-\left|Q_{c}\right|}
$$

Gawai yang melaksanalan daur dalam arah ini disebut pesawat pendingin dan sistem yang mengalami daur ini disebut zat pendingin. Diagram skematik dalam Gambar 2 memperlihatkan lintasan suatu massa tetap zat pendingin ketika mulai dibawa dari penyimpanan cairan pada temperatur dan tekanan pengembun, melalui katup sernak, melewati penguap, masuk kedalam pengampat, dan akhirnya kembali ke pengembun. Didalam pengembun, zat pendingin berada pada tekanan tinggi dan pada temperatur rendah yang bisa dicapai dengan memakai pendingin udara atau air. Zat pendingin ini selalu memiliki sifat sedemikian sehingga pada tekanan dan temperatur ini, zat merupakan cairan jenuh. Bila fluida ini mengalir melalui bukaan sempit (katup jarum) dari daerah tekanan tinggi yang tetap ke daerah tekanan rendah yang tetap seacara adiabat, zat dikatakan mengalami proses sernak atau pemuaian joule Thomson atau pemuaian joule Kelvin. Terdapat sifat cairan jenuh (bukan gas) yang menunjukkan bahwa proses sernak selalu menimbulkan pendinginan dan penguapan parsial. Dalam penguap itu, seluruh fluida dijadikan uap, dan kalor penguapan diambil dari bahan yang didinginkan. Selanjutnya uap dimampatkan secara adiabat, sehingga terjadi kenaikan temperatur. Didalam pengembun uap ini didinginkan sehingga mengembun dan seluruhnya menjadi cairan (Zemasky \& Ditman, 1986). Dengan demikian, zat pendingin atau sering disebut refrigerant sangat berpengaruh terhadap jalannya mesin pendingin karena zat ini yang menyerap panas dari benda atau udara yang ingin didinginkan kedalam sistem dan membawanya, kemudian membuangnya ke bagian udara di sekeliling di luar benda atau udara yang didinginkan. Oleh karena itu, refrigerant atau zat pendingin yang digunakan tentunya adalah zat yang memiliki sifat yang mudah diubah wujudnya dari gas menjadi cair, ataupun sebaliknya.

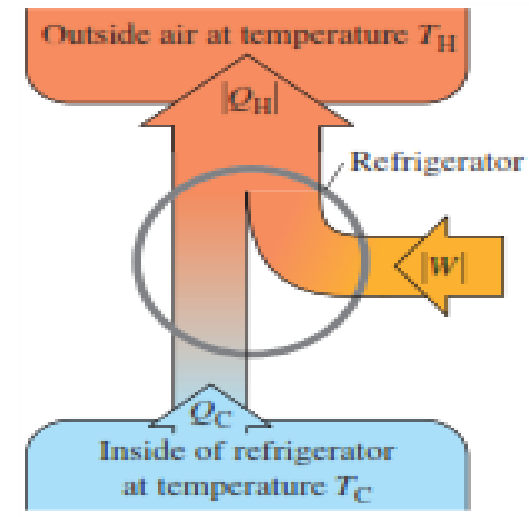

Gambar 1. Gambaran mesin pendingin (Sumber: Young \& Freedman, 2012)

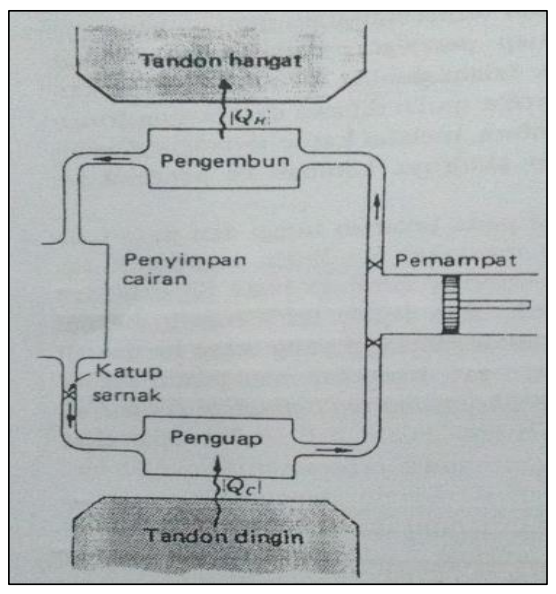

Gambar 2. Instalasi Pendingin Dasar (Sumber: Zemasky \& Ditman, 1986)

CFC (chloro fluoro carbon) atau freon yang terdiri karbon, klorin dan flourin adalah molekul yang telah digunakan selama bertahun-tahun sebagai zat pendingin atau refrigerant sampai tahun 1980an. Molekul ini 
pertama kali disintesis pada tahun 1928. Meskipun molekul ini memiliki sifat termodinamika yang baik sebagai zat pendingin atau refrigerant yaitu karena efisiensi dan kemudahannya. Akan tetapi, jika bahan kimia ini lolos ke atmosfer, molekul ini akan melayang ke stratosfer dan radiasi UV-C yang intens maka akan memecahkan ikatan kimianya, melepaskan klorin yang akan mengalirkan atom dari molekul ozon dan mengurainya menjadi molekul oksigen. Klorin bertugas sebagai katalisator yang menyelesaikan penghancuran ini tanpa mengalami perubahan permanen apapun. Oleh karena itu, dapat terus mengulangi prosesnya. Telah ditemukan bahwa satu atom klor dapat menghancurkan 100.000 molekul ozon. Semakin tinggi kadar klorin senyawa, semakin lama akan berdampak dengan lapisan ozon. Diperkirakan bahwa CFC menyumbang hampir $70 \%$ bahan kimia perusak ozon buatan manusia di atmosfer diukur dengan satuan komparatif yang disebut Ozone Depletion Potential (ODP) (UNEP, 2003).

Ozon adalah varian oksigen, molekul ozon memiliki tiga atom oksigen. Ozon adalah gas beracun dan jika terhirup bisa menyebabkan kematian. Lapisan ozon mengelilingi stratosfer bumi yang berjarak sekitar $11 \mathrm{~km}$ di atas permukaan bumi. Kehidupan di bumi telah dijaga ketat selama ribuan tahun oleh lapisan pelindung kehidupan ini. Ozon bertindak sebagai pelindung untuk melindungi bumi dari radiasi ultraviolet yang berbahaya dari sinar matahari (Bhatti MSA dalam Bolaji \& Huan, 2003)

Lapisan ozon secara efisien menyaring semua sinar ultraviolet yang berbahaya dari sinar matahari dengan menyerap sebagian besar radiasi UV-B yang berbahaya (UV-A diperbolehkan melalui sinar UV-C ditangkap oleh oksigen). Lapisan Ozon adalah pelindung terhadap radiasi UV-B yang berbahaya sehingga kerusakan pada ozon ini dapat menyebabkan kerusakan yang besar pada lingkungan dan kehidupan di bumi. Paparan radiasi UV-B yang meningkat dapat menyebabkan insiden kerusakan mata (seperti katarak, deformasi lensa mata dan presbiopia), menyebabkan kanker kulit, menurunkan tingkat pertumbuhan tanaman, mengganggu keseimbangan ekosistem dan mempercepat risiko penyakit (UNEP, 2000).

CFC adalah gas rumah kaca sehingga jika molekul ini lolos ke atmosfer maka akan mengakibatkan efek rumah kaca sehingga menimbulkan pemanasan global. Hwang (dalam Bolaji \& Huan, 2003) menjelaskan bahwa salah satu penyebab potensi pemanasan global adalah emisi zat pendingin. Peningkatan konsentrasi gas rumah kaca di atmosfer menyebabkan jumlah radiasi inframerah yang diserap meningkat, dan menyebabkan meningkatnya suhu atmosfer dan akibatnya perubahan iklim jangka panjang. Jumlah energi radiasi yang dikonsumsi oleh zat pendingin diukur dengan indeks yang disebut Global Warming Potential (GWP). GWP adalah jumlah radiasi inframerah yang dapat diserap gas, relatif terhadap karbon dioksida dan terintegrasi dalam jangka waktu 100 tahun.

\section{Tinjauan Etika terhadap Penggunaan Freon Untuk Mesin Pendingin dalam Filsafat IImu}

Sejak awal perkembangan ilmu pengetahuan, pertumbuhan ilmu pengetahuan, pertumbuhan ilmu tidak dapat dilepaskan dari masalah moral. Dalam setiap teknologi yang dihasilkan didalamnya terkandung nilai-nilai dan moralitas dalam kehidupan. Penggunaan ilmu dan teknologi yang didasari nilai-nilai moral dapat menyebablan pelanggaran nilainilai kemanusiaan dan moral itu sendiri. Kehidupan manusia yang tidak dapat dilepaskan dari agama telah memberikan batasan tentang, tata nilai dan moral yang sekaligus membatasi penggunaan ilmu dan teknologi untuk selalu taat akan nilai-nilai dan moral. Pada sebagian orang, pada pengikut paham ilmu yang bebas nilai telah berjuang agar ilmu memperoleh otonomi dalam melakukan penelitian dalam rangka mempelajari alam sebagaimana adanya (Suriasumantri, 2010).

Sasaran pemanfaatan bagi kelangsungan kehidupan berarti bahwa teknologi seharusnya difungsikan untuk menjaga kelestarian lingkungan hidup dan sumber daya alam. Dengan teknologi, nilai kebenaran universal ontologis diberdayakan 
dalam bentuk sikap dan perilaku ilmiah untuk memproduksi sumber daya alam sesuai dengan kebutuhan hidup, demi tercapainya tujuan kesejahteraan dan kebahagiaan bagi seluruh umat manusia. Dengan memberdayakan teknologi seperti itu, kehidupan kita terhindar dari eksploitasi dan cenderung menguras sumber daya alam dan merusak lingkungan hidup (Suhartono, 2005).

Potensi teknologi manusia seharusnya mampu dan mau untuk pertama kali bersikap dan berperilaku adil dan bertanggung jawab terhadap lingkungan hidup dan sumber daya alam. Hal ini berarti manusia memprioritaskan sikap dan perilaku adil terhadap semua makhluk lainnya. Langkah selanjutnya adalah mampu dan mau bersikap adil terhadap sesama manusia. Dari situ barulah manusia mampu dan mau bersikap adil terhadap diri sendiri. Sistematika sikap dan perilaku manusia harus diputar baik secara demikian itu, dengan alsan bahwa fakta membuktikan: pertama, manusia tidak bisa hidup tanpa keseimbangan ekosistem dan ketersediaan sumber daya alam yang cukup; kedua, manusia tidak bisa hidup tanpa kerjasama dengan sesama manusia lain; ketiga, manusia tidak mampu mempertahankan dan mengemabangkan kehidupannya tanpa potensi individual berupa inisiatif dan kreativitas. Secara eksistensial, fakta konkret membuktikan bahwa "bukankah manusia dari alam, oleh alam, dan untuk alam? Bagi hidup dan kehidupan manusia, alam dengan potensi sumber dayanya berfungsi untuk menentukan (Suhartono, 2005).

Seorang ilmuwan sebenarnya tidak dapat berbuat banyak untuk mencegah penyalahgunaan hasil penemuan mereka. Memang manusia tampaknya tetap cenderung untuk menciptakan dilema pada tiap hasil penemuannya, jadi seperti menciptakan pedang yang bermata dua, yaitu suatu mata dipakai untuk meningkatkan kesejahteraan, mata yang lain dipakai untuk mendatangkan kerusakan (Semiawan dkk, 1988). Seperti pada teknologi mesin pendinginan yang memainkan peran penting dalam kehidupan yaitu menyediakan lingkungan hidup yang nyaman dan sehat serta dianggap sebagai kebutuhan untuk bertahan dari cuaca buruk dan melestarikan makanan. Akan tetapi disisi lain, teknologi mesin pendingin dengan freon bisa mengancam lingkungan melalui penipisan lapisan ozon dan pemanasan global (UNEP, 2003). Bumi adalah satu-satunya planet di tata surya dengan suasana yang mendukung kehidupan. Oleh karena itu, pelestarian lapisan ozon dan pengurangan pelepasan gas rumah kaca adalah bagian dari banyak langkah penting yang diperlukan untuk melindungi kehidupan di planet ini untuk generasi mendatang. Untuk itu, masalah yang diakibatkan oleh teknologi mesin pendingin dengan freon ini harus dipertanggungjawabkan untuk mewujudkan perubahan yang terbaik dalam teknologi mesin pendingin demi pembangunan masa depan.

Tanggung jawab ilmu pengetahuan dan teknologi menyangkut juga tanggung jawab terhadap hal-hal yang akan dan telah diakibatkan ilmu pengetahuan dan teknologi di masa lalu, sekarang maupun apa akibatnya bagi masa depan berdasar keputusan bebas manusia dalam kegiatannya. Penemuanpenemuan baru dalam ilmu pengetahuan dan teknologi terbukti ada yang dapat mengubah sesuatu aturan baik alam maupun manusia. Hal ini tentu saja menuntut tanggung jawab untuk selalu menjaga agar apa yang diwujudkannya dalam perubahan tersebut akan merupakan perubahan yang terbaik bagi perkembangan ilmu pengetahuan dan teknologi itu sendiri maupun bagi perkembangan eksistensi manusia secara utuh (Achmad Charris Zubair dalam Suhartono, 2005).

Hukum sebagai landasan etika moral ilmuan haruslah dijabarkan dan diimplementasikan dalam realitas kemasyarakatan dan sistem kenegaraan. Terlebih ditengah perkembangan ilmu pengetahuan dan teknologi seperti saat ini, semua orang bebas mengembangkan atau menikmati teknologi dengan tanpa memperhatikan etika moral keilmuan, dan hanya mengedepankan aspek material atau finansial bisnis, atau untuk kepentingan pribadi saja. Jadi etika moral harus mengikat para pihak, baik ilmuan, pemakai atau pengguna, maupun produsen atau pihak dunia industri yang menghasilkan produk ilmu pengetahuan 
dan teknologi harus maslahat bagi kehidupan manusia, bukan justru untuk kemudaratan dan memusnahkan budaya, peradaban dan kehidupan manusia (Latif, 2014).

Pemecahan masalah terhadap dampak dari penggunaan freon untuk mesin pendingin telah dilakukan oleh semua pihak yaitu baik ilmuan, pemerintah, pengguna maupun produsen. International Institute of Refrigeration (IIR) telah melakukan banyak hal untuk mengurangi konsumsi energi dari pendingin di masa depan yaitu (Coulumb, 2008):

1. Meningkatkan penelitian dan pengembangan di bidang pendingin alami untuk memastikan bahwa pendingin ini akan menjadi pendingin pilihan;

2. Mempromosikan pendingin pilihan (HFC atau pendingin alami) yang paling ramah lingkungan.

3. Melanjutkan untuk tidak menggunakan CFCs dan HFCs karena berdampak pada penipisan lapisan ozon dan pemanasan global. Dalam pengembangan negara, lebih baik mengganti CFCs secara langsung dengan HFCs atau pendingin alami.

IIR yang menghadapi tantangan ini, melakukan sejumlah tindakan (Coulumb, 2008):

1. IIR mengambil bagian dalam pertemuan internasional di Protokol Montreal dan Kyoto: ia mampu menyajikan sudut pandangnya kepada semua pejabat pemerintah di bidang lingkungan hidup diberbagai negara.

2. IIR menyelenggarakan scientific and technical conferences tentang solusi teknologi yaitu konfrensi tentang fluida yang bekerja secara ilmiah, konfrensi tentang ammonia, dan konfrensi tentang pendinginan.

3. IIR menerbitkan buku, kursus, munual dan informasi tentang catatan lingkungan. Buku edisi terbarunya adalah Panduan Penghematan Energi di Indonesia untuk mengatasi semua perkembangan terkini dalam bidang konteks perubahan iklim.

Setelah CFC refrigeran Montreal (1987)

CFC (chloro fluoro carbons) akhirnya ditinggalkan pada tahun 2000 dan secara bertahap diganti oleh HCFC dan di dalamnya memberikan kesempatan bagi pengembangan pengganti (Benhadid-Dib \& Benzaoui, 2012). CFC telah dilarang dibeberapa negara yaitu kebanyakan negara maju dan negara-negara transisi seperti Bulgaria. Selain itu, telah dilarang di negara-negara berkembang sejak tahun 2010. HCFCs akan dilarang pada tahun 2030 dan 2040. Eropa telah melarang sejak tahun 2015 (Coulumb, 2008).

Berikut ini adalah peraturan EU 2037/2000 dan 842/2006 (Benhadid-Dib \& Benzaoui, 2012):

1. Penggunaan HCFCs dengan dampak tinggi pada efek rumah kaca harus dihentikan secara permanen 2015;

2. Penggantian bertahap HCFCs dengan HFCs;

3. Penahanan pendinginan untuk mengurangi jumlah zat pendingin;

4. Pada tahun 2015, penggunaan HFCs lowGWP

Selain itu, direkomendasikan untuk mengurangi dan menghentikan produksi gas yang paling berbahaya bagi lapisan ozon dan yang memiliki dampak signifikan pada efek rumah kaca yaitu zat pendingin yang molekulnya kaya akan klorin 2006 (BenhadidDib \& Benzaoui, 2012).

Konferensi yang diikuti menyoroti tren dan tenggat waktu yang dipersingkat yaitu konferensi Kopenhagen sehingga diputuskan untuk menghentikan produksi CFCs pada tanggal 31 Desember 1994 dan HCFC pada tanggal 31 Desember 2014. CFCs dihapus secara permanen kecuali dalam jumlah kecil dan ketika sangat sangat diperlukan 2006 (Benhadid-Dib \& Benzaoui, 2012).

\section{PENUTUP}

Dari paparan di atas dapat diambil kesimpulan sebagai berikut:

1. Dalam filsafat ilmu, etika merupakan prinsip perilaku manusia yang kadang-kadang disebut moral.

2. Freon untuk mesin pendingin merupakan molekul yang baik untuk digunakan sabagai zat pendingin karena efisiensi dan kemudahannya. 


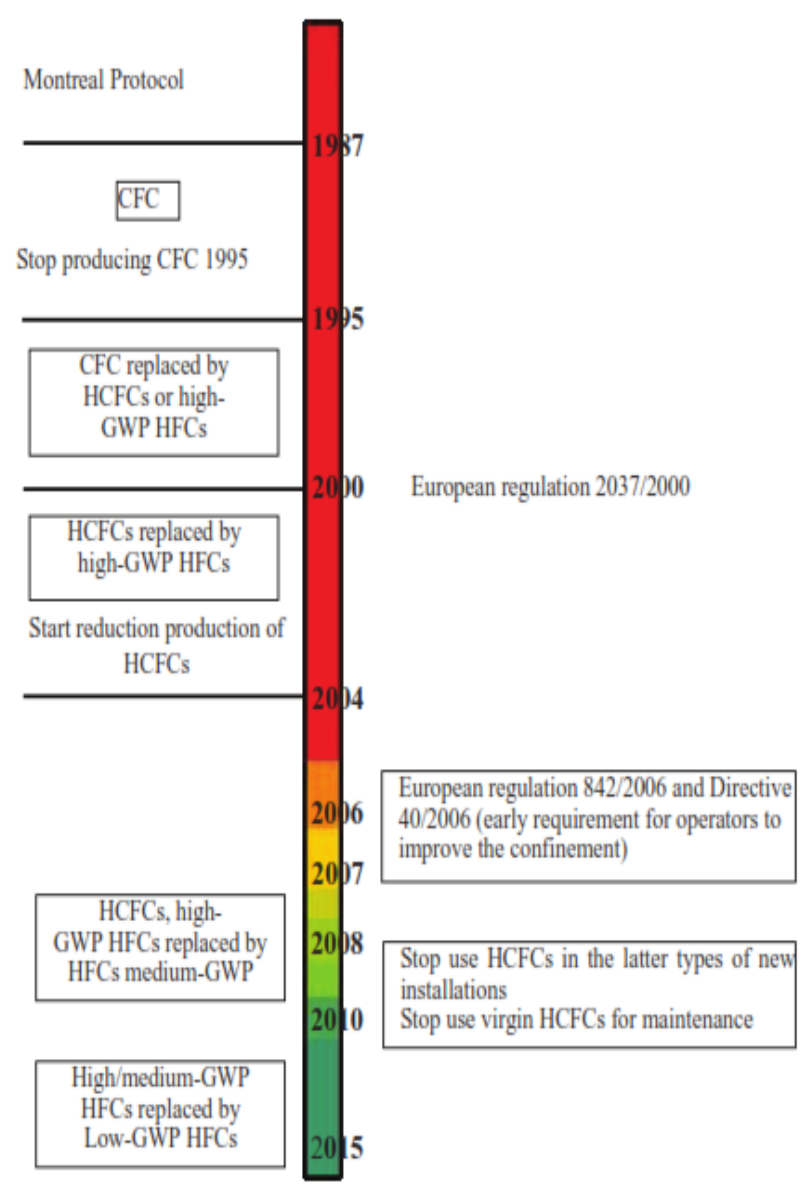

Gambar 3. Peraturan Eropa tentang penggunaan cairan (Sumber: Règlement européen CE)

3. Ditinjau dari sudut etika, penggunaan freon untuk mesin pendingin yang dapat mengancam lingkungan melalui penipisan ozon dan pemanasan global sebaiknya dihentikan dan menggantinya dengan pendingin yang lebih baik. Semua pihak harus bertanggung jawab dalam mengatasi masalah penggunaan freon untuk mesin pendingin yang memiliki dampak negatif ini.

\section{UCAPAN TERIMAKASIH}

Saya ingin mengucapkan terima kasih kepada Dosen Pengampu mata kuliah Filsafat ilmu Dr. Harry Firman, M.Pd, yang telah memberikan bimbingan tentang materi Filsafat Ilmu sehingga tulisan ini dapat disusun dengan baik.

\section{DAFTAR PUSTAKA}

Benhadid-Dib, S. \& Benzaoui, A. (2012). Refrigerants and their environmental impact Substitution of hydro chlorofluorocarbon HCFC and HFC hydro fluorocarbon. Search for an adequate refrigerant. Energy Procedia, $18,807-816$.

Bolaji, B.O. \& Huan, Z.(2003). Ozone depletion and global warming: Case for the use of natural refrigerant - a review. Renewable and Sustainable Energy Reviews, 18, 49-54.

Coulomb, D. (2008). Refrigeration and cold chain serving the global food industry and creatin a better future: two key IIR challenges for improved health and environment. Trends in Food Science \& Technology, 19.

Firman, H. (2017). Etika Sains. Bahan Kuliah Filsafat IImu, Sekolah Pascasarjana Universitas Pendidikan Indonesia, Bandung.

Latif, M. (2014). Orientasi Ke Arah Pemahaman Filsafat IImu. Jakarta: Kencana Prenada Media Group.

Ihsan, A. F. (2010). Filsafat IImu. Jakarta: Rineka Cipta.

UNEP.(2003). United Nation environment program. Handbook for International treaties for protection of the ozone layers 6th ed. Nairobi, Kenya.

UNEP.(2000). United Nation environment program. Handbook for International treatics for protection of the ozone layers, 5th ed. Nairobi, Kenya.

Suhartono, S. (2008). Filsafat IImu Pengetahuan: Persoalan Eksistensi dan Hakikat IImu Pengetahuan. Jogjakarta: Ar-Ruzz Media.

Suriasumantri. J.S.(2010). Filsafat IImu Sebuah Pengantar Populer. Jakarta: Pustaka Sinar Harapan.

Young, H.D. \& Freedman R.A., (2012). Sears and Zemansky's University Physics: With Modern Physics, - 13th ed. San Fransisco: Addison-Wesley.

Zemansky, M.W \& Dittman, R.H. (1986). Kalor dan Termodinamika. Bandung: Penerbit ITB. 